\title{
Social Capital: Implications for Development Theory, Research, and Policy
}

In the 1990s the concept of social capital-defined here as the norms and networks that enable people to act collectively-enjoyed a remarkable rise to prominence across all the social science disciplines. The authors trace the evolution of social capital research as it pertains to economic development and identify four distinct approaches the research has taken: communitarian, networks, institutional, and synergy. The evidence suggests that of the four, the synergy view, with its emphasis on incorporating different levels and dimensions of social capital and its recognition of the positive and negative outcomes that social capital can generate, has the greatest empirical support and lends itself best to comprehensive and coherent policy prescriptions. The authors argue that a significant virtue of the idea of and discourse on social capital is that it helps to bridge orthodox divides among scholars, practitioners, and policymakers.

What is social capital? How does it affect economic development? What are the implications for theory, research, and policy? These questions lie at the heart of recent attempts to make sense of the burgeoning literature on social capital and to ascertain its relationship to economic development. In this article we endeavor to answer each of these questions; in so doing, we provide an overview of the scholarship on social capital for those unfamiliar with the term as well as a sense of coherence and direction to those embarking on new empirical research and policy analysis in this rich field.

\section{What Is Social Capital?}

"It's not what you know, it's who you know." This common aphorism sums up much of the conventional wisdom regarding social capital. It is wisdom born of 
experience-that gaining membership to exclusive clubs requires inside contacts, that close competitions for jobs and contracts are usually won by those with friends in high places. When people fall on hard times, they know it is their friends and family who constitute the final safety net. Conscientious parents devote hours to the school board and to helping their children with homework, only too aware that a child's intelligence and motivation are not enough to ensure a bright future. Some of our happiest and most rewarding hours are spent talking with neighbors, sharing meals with friends, participating in religious gatherings, and volunteering for community projects.

Intuitively, then, the basic idea of social capital is that a person's family, friends, and associates constitute an important asset, one that can be called on in a crisis, enjoyed for its own sake, and leveraged for material gain. What is true for individuals, moreover, also holds for groups. Those communities endowed with a diverse stock of social networks and civic associations are in a stronger position to confront poverty and vulnerability (Moser 1996; Narayan 1995), resolve disputes (Schafft 1998; Varshney 2000), and take advantage of new opportunities (Isham 1999). Conversely, the absence of social ties can have an equally important impact. Office workers, for example, fear being left out of the loop on important decisions; ambitious professionals recognize that getting ahead in a new venture typically requires an active commitment to networking. A defining feature of being poor, moreover, is that one is not a member of - or may even be actively excluded from-certain social networks and institutions that could be used to secure good jobs and decent housing (Wilson 1987, 1996).

Intuition and everyday language also recognize an additional feature of social capital: that it has costs as well as benefits, that social ties can be a liability as well as an asset. Most parents, for example, worry that their teenage children will fall in with the wrong crowd and that peer pressure and a strong desire for acceptance will induce them to take up harmful habits. Even close family members can overstay their welcome. At the institutional level, many countries and organizations have nepotism laws, in explicit recognition that personal connections can be used to discriminate unfairly, distort, and corrupt. Everyday language and life experience, in short, teach that the social ties individuals have can be both a blessing and a blight, while those they do not have can deny them access to key resources. These features of social capital are well documented by the empirical evidence and have important implications for economic development and poverty reduction.

These examples suggest a more formal definition: social capital refers to the norms and networks that enable people to act collectively. This simple definition serves a number of purposes. First, it focuses on the sources, rather than the consequences, of social capital (Portes 1998) while recognizing that important features of social capital, such as trust and reciprocity, are developed in an iterative process. Second, this definition permits the incorporation of different dimensions of social capital and 
recognizes that communities can have access to more or less of them. The poor, for example, may have a close-knit and intensive stock of "bonding" social capital that they can leverage to "get by" (Briggs 1998; Holzmann and Jorgensen 1999), but they lack the more diffuse and extensive "bridging" social capital deployed by the nonpoor to "get ahead" (Barr 1998; Kozel and Parker 2000; Narayan 1999). Accordingly, such an approach allows the argument that it is different combinations of bonding and bridging social capital that are responsible for the range of outcomes observed above and incorporates a dynamic component in which optimal combinations of these dimensions change over time. Third, while this definition presents the community (rather than individuals, households, or the state) as the primary unit of analysis, it recognizes that individuals and households (as members of a given community) can nonetheless appropriate social capital and that the way communities themselves are structured turns in large part on their relationship with the state. Weak, hostile, or indifferent governments have a profoundly different effect on community life and development projects, for example, than do governments that respect civil liberties, uphold the rule of law, honor contracts, and resist corruption (Isham and Kaufmann 1999).

This conceptualization of the role of social relationships in development represents an important departure from earlier theoretical approaches and therefore has important implications for contemporary development research and policy. Until the 1990s the major theories of development held rather narrow, even contradictory, views about the role of social relationships in economic development and offered few constructive policy recommendations. In the 1950s and 1960s, for example, traditional social relationships and ways of life were viewed as impediments to development. When modernization theorists explained "the absence or failure of capitalism," Moore (1997:289) correctly notes, "the focus [was] on social relations as obstacles." As an influential United Nations (1951) document of the time put it, for development to proceed, "ancient philosophies have to be scrapped; old social institutions have to disintegrate; bonds of caste, creed and race have to burst; and large numbers of persons who cannot keep up with progress have to have their expectations of a comfortable life frustrated" (cited in Escobar 1995:3).

This view gave way in the 1970s to the arguments of dependency and worldsystems theorists, who held that social relations among corporate and political elites were a primary mechanism of capitalist exploitation. The social characteristics of poor countries and communities were defined almost exclusively in terms of their relation to the means of production and the inherent antipathy between the interests of capital and labor. Little mention was made of the possibility (or desirability) of mutually beneficial relationships between workers and owners, of the tremendous variation in the degree of success recorded by developing countries, or of political strategies-other than revolution-by which the poor could improve their lot. At the same time, communitarian perspectives stressed the inherent beneficence and 
self-sufficiency of local communities but underestimated the negative aspects of communal obligations, overestimated the virtues of isolationism and self-sufficiency, and neglected the importance of social relations in constructing effective and accountable formal institutions. For their part, neoclassical and public choice theoristswhose voices were the most influential in the 1980s and early 1990s-assigned no distinctive properties to social relations. These perspectives, which focused on the strategic choices of rational individuals interacting under various time, budgetary, and legal constraints, held that groups (including firms) existed primarily to lower the transaction costs of exchange; given undistorted market signals, the optimal size and combination of groups would duly emerge.

The major development theories, then, construed social relations as singularly burdensome, exploitative, liberating, or irrelevant. Reality, unfortunately, does not conform so neatly to these descriptions and their corresponding policy prescriptions. Events in the post-cold war era-from ethnic violence and civil war to financial crises and the acknowledgement of widespread corruption-demand a more sophisticated appraisal of the vices, virtues, and vicissitudes of the social dimension as it pertains to the wealth and poverty of nations (Woolcock forthcoming). The literature on social capital, in its broadest sense, represents a first approximation to the answer to this challenge. It is a literature to which all the social science disciplines have contributed, and it is beginning to generate a remarkable consensus regarding the role and importance of institutions and communities in development. Indeed, one of the primary benefits of the idea of social capital is that it allows scholars, policymakers, and practitioners from different disciplines to enjoy an unprecedented level of cooperation and dialogue (Brown 1998; Brown and Ashman 1996).

\section{Four Perspectives on Social Capital and Economic Development}

The letter and spirit of social capital have a long intellectual history in the social sciences (Platteau 1994; Woolcock 1998), but the sense in which the term is used today dates back more than 80 years to the writings of Lyda J. Hanifan, then the superintendent of schools in West Virginia. Explaining the importance of community participation in enhancing school performance, Hanifan (1916:130) invoked the concept of social capital, describing it as

those tangible substances [that] count for most in the daily lives of people: namely good will, fellowship, sympathy, and social intercourse among the individuals and families who make up a social unit. . . . If [an individual comes] into contact with his neighbor, and they with other neighbors, there will be an accumulation of social capital, which may immediately satisfy his 
social needs and which may bear a social potentiality sufficient to the substantial improvement of living conditions in the whole community.

After Hanifan the idea of social capital disappeared for several decades but was reinvented in the 1950 s by a team of Canadian urban sociologists (Seely, Sim, and Loosely 1956), in the 1960s by an exchange theorist (Homans 1961) and an urban scholar (Jacobs 1961), and in the 1970s by an economist (Loury 1977). None of these writers, interestingly, cited earlier work on the subject, but all used the same umbrella term to encapsulate the vitality and significance of community ties. The seminal research by Coleman $(1987,1988,1990)$ on education and by Putnam $(1993,1995)$ on civic participation and institutional performance, however, has provided the inspiration for most of the current work, which has since coalesced around studies in nine primary fields: families and youth behavior; schooling and education; community life (virtual and civic); work and organizations; democracy and governance; collective action; public health and environment; crime and violence; and economic development. ${ }^{1}$

In this paper we are concerned with this final category and related work in political economy and new institutional economics. Research on social capital and economic development can be categorized into four distinct perspectives: the communitarian view, the networks view, the institutional view, and the synergy view.

\section{The Communitarian View}

The communitarian perspective equates social capital with such local organizations as clubs, associations, and civic groups. Communitarians, who look at the number and density of these groups in a given community, hold that social capital is inherently good, that more is better, and that its presence always has a positive effect on a community's welfare. This perspective has made important contributions to analyses of poverty by stressing the centrality of social ties in helping the poor manage risk and vulnerability. As Dordick (1997) notes, the poor have "something left to lose"each other.

In their celebration of community and civil society, however, many enthusiasts of this view of social capital have ignored its important downside (Portes and Landolt 1996). For example, where communities or networks are isolated, parochial, or working at cross-purposes to society's collective interests (in ghettos, gangs, drug cartels, and so on), productive social capital is replaced by what Rubio (1997)_-in discussing Colombia — calls perverse social capital, which greatly hinders development. Many benefits certainly are associated with being a member of a highly integrated community, but there are also significant costs, and for some, the costs may greatly outweigh the benefits. Consider, for instance, the bright girls who are taken out of village schools in India because of community expectations. The social networks underly- 
ing organized crime syndicates in Latin America and Russia may generate large negative externalities for society in the form of lost lives, wasted resources, and pervasive uncertainty. The communitarian perspective also implicitly assumes that communities are homogenous entities that automatically include and benefit all members. But the extensive literature on caste inequality, ethnic exclusion, and gender discrimination-the bleak outcomes often produced and maintained by community pressuressuggests otherwise (Narayan and Shah 1999).

Evidence from the developing world demonstrates why merely having high levels of social solidarity or informal groups does not necessarily lead to economic prosperity. In Kenya a participatory poverty assessment recorded more than 200,000 community groups active in rural areas, but most were unconnected to outside resources and were unable to improve the lot of the poor (Narayan and Nyamwaya 1996). A World Bank (1989) report on Rwanda cited more than 3,000 registered cooperatives and farmers groups and an estimated 30,000 informal groups, yet these groups were unable to prevent one of history's most gruesome civil wars. In many Latin American countries, indigenous groups are often marked by high levels of social solidarity, but they remain excluded economically because they lack the resources and access to power that are necessary to shift the rules of the game in their favor (Narayan 1999). This is also the case in Haiti, where social capital, "rich at the local level," is employed by peasant groups to "meet labor requirements, gain access to land, protect clientship in the marketplace, promote mutual aid, assure protection from state authorities, and generally manage risk." Even so, these groups cannot overcome the crippling effects of colonialism, corruption, "geographical isolation, political exclusion, and social polarization" (all quotations from White and Smucker 1998:1-3).

\section{The Networks View}

A second perspective on social capital, which attempts to account for both its upside and its downside, stresses the importance of vertical as well as horizontal associations between people and of relations within and among such organizational entities as community groups and firms. Building on work by Granovetter (1973), it recognizes that strong intracommunity ties give families and communities a sense of identity and common purpose (Astone and others 1999). This view also stresses, however, that without weak intercommunity ties, such as those that cross various social divides based on religion, class, ethnicity, gender, and socioeconomic status, strong horizontal ties can become a basis for the pursuit of narrow sectarian interests. In the recent popular literature, the former has been called "bonding" and the latter "bridging" social capital (Gittell and Vidal 1998). Different combinations of these dimensions, it is argued, are responsible for the range of outcomes that can be attributed to social capital. This more nuanced perspective, which we call the networks view, re- 
gards the tension between social capital's virtues and vices as a defining property, one that explains in part why scholars and policymakers have been so persistently ambivalent about its potential as a theoretical construct and policy instrument.

The networks view of social capital is closely associated with Burt (1992, 1997, 1998); Fafchamps and Minten (1999); Massey (1998); Massey and Espinosa (1997); Portes (1995, 1997, 1998); and Portes and Sensenbrenner (1993). It is characterized by two key propositions. First, social capital is a double-edged sword. It can provide a range of valuable services for community members, ranging from baby-sitting and house-minding to job referrals and emergency cash. But there are also costs in that those same ties can place considerable noneconomic claims on members' sense of obligation and commitment, with negative economic consequences. Group loyalties may be so strong that they isolate members from information about employment opportunities, foster a climate of ridicule toward efforts to study and work hard, or siphon off hard-won assets (say, to support recent immigrants from the home country). Portes and Sensenbrenner (1993) cite the case of prosperous Asian immigrants who anglicized their names in order to divest themselves of communal obligations to subsequent cohorts. Second, the sources of social capital need to be distinguished from the consequences derived from them. Imputing only desirable outcomes to social capital, or equating them with it, ignores the possibility that these outcomes may be attained at another group's expense, that given outcomes may be suboptimal, or that desirable outcomes attained today come at the price of significant costs tomorrow.

These results have given rise to the logical conclusion that both strong intracommunity ties and weak extracommunity networks are needed to avoid making tautological claims regarding the efficacy of social capital. (Without this distinction, for example, it could be argued that successful groups are distinguished by their dense community ties, failing to consider the possibility that the same ties could be preventing success in another otherwise similar group.) Accordingly, the networks view argues that communities can be characterized by their endowments of these two dimensions of social capital and that different combinations of these dimensions account for the range of outcomes associated with social capital (table 1).

Furthermore, as community members' welfare changes over time, so too does the optimal calculus of costs and benefits associated with particular combinations of bonds and bridges. Poor entrepreneurs, for example, initially dependent on their

Table 1. Dimensions of Social Capital at the Community Level

\begin{tabular}{lll}
\hline Extracommunity networter & \multicolumn{2}{c}{ Intracommunity ties (bonding) } \\
\cline { 2 - 3 } (bridging) & Low & High \\
\hline Low & Outcasts & Poor villagers \\
High & Recent rural-to-urban & Successful members of \\
& migrants & microfinance programs \\
\hline
\end{tabular}


immediate neighbors and friends (their bonding social capital) for credit, insurance, and support, require access to more extensive product and factor markets as their businesses expand. Granovetter (1995) argues that economic development takes place through a mechanism that allows individuals to draw initially on the benefits of close community membership but that also enables them to acquire the skills and resources to participate in networks that transcend their community, thereby progressively joining the economic mainstream.

These insights can be demonstrated graphically and applied to poverty reduction more generally. Figure 1 shows that as the social networks of the poor become more diverse, so too does their welfare. The social capital residing in a given network can be leveraged or used more efficiently, which is essentially the genius of group-based credit programs such as the well-known Grameen Bank in Bangladesh (van Bastelaer 1999). Poor village women with no material collateral are given loans on the basis of their membership in a small peer group, which helps them start or expand a small business and thereby improve their families' welfare (A). But the economic returns

Figure 1. Social Capital and Poverty Transitions

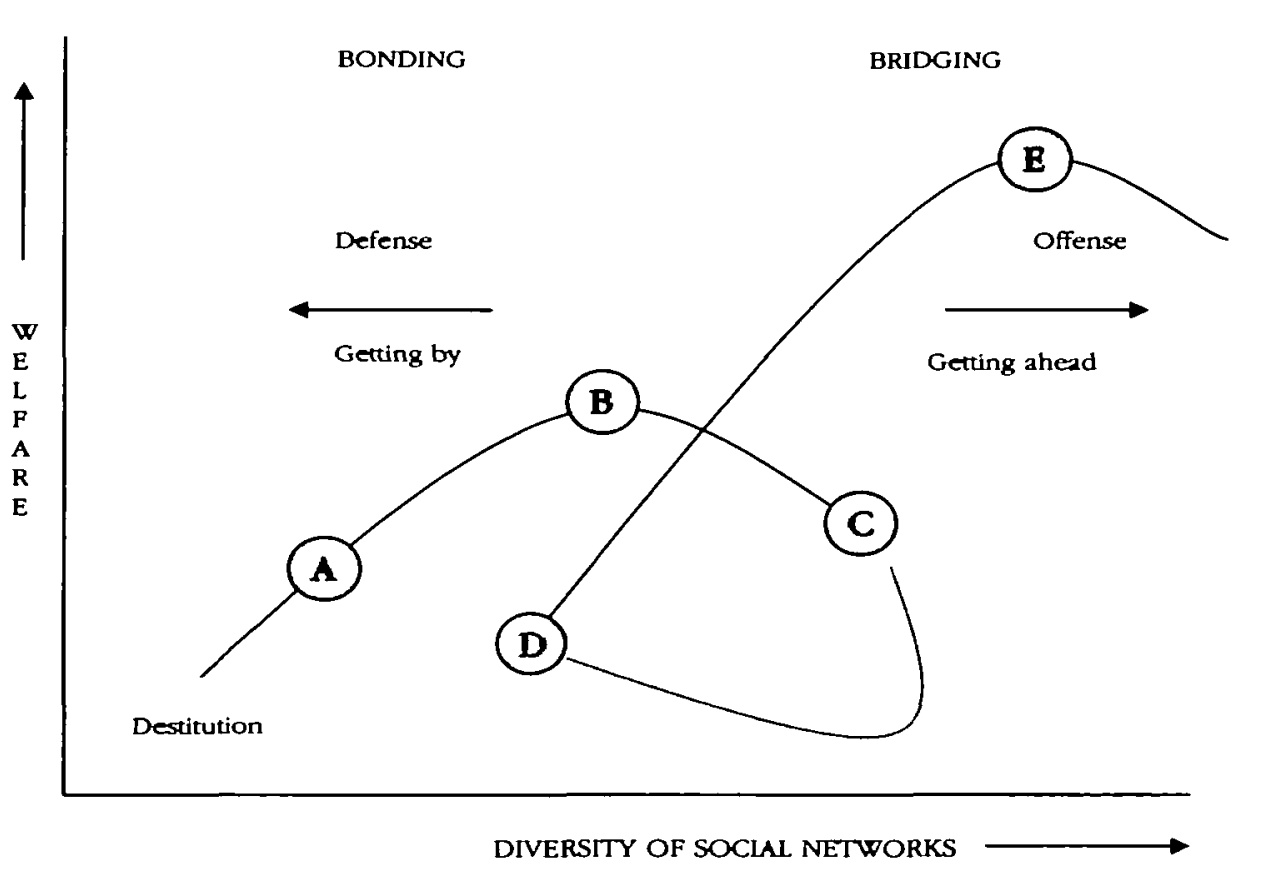

Sounce: Woolcock (2000). 
to any given group soon reach a limit (B), especially when they rely on high endowments of "bonding" social capital. If the group continues to expand-for example, through the arrival of subsequent cohorts from the village-its resources may become overwhelmed, thereby reducing the well-being of long-established members (C). Similarly, long-term members of group-based credit programs may find that obligations and commitments to their colleagues present obstacles to further advancement, especially for the more ambitious (Woolcock 1999). In these circumstances, many poor people partially divest themselves of their immediate community ties (D) and find a potentially more diverse network where "bridging" social capital is more abundant and economic opportunities more promising (E). Migration from villages to cities is the most dramatic example of this situation, but Portes and Sensenbrenner's (1993) name-changing Asian immigrants are doing essentially the same thing.

The networks view has been employed with great effect in recent development research. In their analysis of poor communities in rural areas of northern India, for example, Kozel and Parker (2000) report that social groups among poor villagers serve vitally important protection, risk management, and solidarity functions. It is the more extensive and leveraged networks of the nonpoor, by contrast, that are used for strategic advantage and the advancement of material interests. Crudely put, the networks of the poor play defense, while those of the nonpoor play offense. Barr (1998) reports strikingly similar results from her work on the relationship between the structure of business networks and enterprise performance in Africa. Poor entrepreneurs, operating small local firms in traditional industries, form what Barr calls solidarity networks to exchange personal information about members' conduct and intentions. The primary function of these networks is to reduce risk and uncertainty. Larger regional firms, in contrast, coalesce into innovation networks that share knowledge about technology and global markets with the explicit goal of enhancing enterprise profit, productivity, and market share (see also Van Dijk and Rabellotti 1997; Fafchamps and Minten 1999). Far from dismissing the vitality of traditional village groups in poor communities (the modernization view) or romanticizing it (the communitarian view), the networks view in effect recognizes that these groups can both help and hinder economic advancement.

The clear challenge to social capital theory, research, and policy from the networks perspective is thus to identify the conditions under which the many positive aspects of bonding social capital in poor communities can be harnessed and its integrity retained (and, if necessary, its negative aspects dissipated), while simultaneously helping the poor gain access to formal institutions and a more diverse stock of bridging social capital. This process is fraught with multiple dilemmas, however, especially for external nongovernmental organizations, extension services, and development agencies, because it may entail altering social systems that are the product of longstanding cultural traditions or of powerful vested interests. 
The particular strength of the networks view is its willingness to engage in detailed policy discussions on the basis of compelling empirical evidence and detailed assessments of the veracity of competing explanations. This view, however, minimizes the "public good" nature of social groups, regarding any benefits of group activity as primarily the property of the particular individuals involved. Its proponents thus are highly skeptical of arguments that social capital can (or should) be measured across larger social aggregates, such as societies or nations (Portes 1998). Neither does the networks approach explicitly incorporate institutions at the societal level and their capacity to both shape and be shaped by local communities. To be sure, the networks perspective recognizes that weak laws and overt discrimination can undermine efforts by poor minorities to act in their collective interest, but the role communities play in shaping institutional performance generally, and the enormous potential of positive state-society relations in particular, are largely ignored.

\section{The Institutional Vlew}

A third perspective of social capital, which we call the institutional view, argues that the vitality of community networks and civil society is largely the product of the political, legal, and institutional environment. Where the communitarian and networks perspectives largely treat social capital as an independent variable giving rise to various outcomes, both good and bad, the institutional view instead views social capital as a dependent variable. This approach argues that the very capacity of social groups to act in their collective interest depends on the quality of the formal institutions under which they reside (North 1990). It also stresses that the performance of states and firms themselves depends on their own internal coherence, credibility, and competence and on their external accountability to civil society.

Research from the institutional view has two variants, both of which have yielded remarkably complementary results. The first approach, described by Skocpol (1995, 1996), encompasses case studies based on comparative history and contends that it is wrong to argue that firms and communities thrive to the extent that governments retreat. On the contrary, Skocpol shows, civil society thrives to the extent that the state actively encourages it. Tendler's (1997) research on the political economy of decentralization in Brazil similarly stresses the importance of good government for making local programs work.

A second, and increasingly influential, approach relies on quantitative crossnational studies of the effects of government performance and social divisions on economic performance. This approach, pioneered by Knack and Keefer $(1995,1997)$, equates social capital with the quality of a society's political, legal, and economic institutions. Drawing on various indexes of institutional quality compiled by investment agencies and human rights groups, these studies show that items such as "generalized trust," "rule of law," "civil liberties," and "bureaucratic quality" are positively 
associated with economic growth. In a recent review of this particular strand of the literature, Knack (1999:28) concludes that "social capital reduces poverty rates and improves, or at a minimum does not worsen, income inequality."

Collier and Gunning (1999) employ a variation of this view in their analyses of the causes of slow growth in Africa (see also Collier 1998, 1999; Temple 1998). Distinguishing between civic and government social capital, they show that slow growth occurs in societies with both high levels of ethnic fragmentation and weak political rights. Although Rodrik $(1998,1999)$ does not employ the terminology of social capital, he makes a similar argument, demonstrating that economies with divided societies and weak institutions for managing conflict respond sluggishly to shocks. Easterly (2000) also reports that societies able to generate and sustain a middleclass consensus are those most likely to produce stable and positive rates of growth. The related literature on social capabilities and development (Hall and Jones 1999; Temple and Johnson 1998) tells a similar story.

Several empirical and methodological questions can be raised about these studies, but in aggregate their message is loud and clear. Rampant corruption, frustrating bureaucratic delays, suppressed civil liberties, vast inequality, divisive ethnic tensions, and failure to safeguard property rights (to the extent that they exist at all) are major impediments to prosperity. In countries where these conditions prevail, there is little to show for well-intentioned efforts to build schools, hospitals, roads, and communications infrastructure or to encourage foreign investment (World Bank 1998). Investments in civic and government social capital are thus highly complementary to investments in more orthodox forms of capital accumulation.

The very strength of the institutional view in addressing macroeconomic policy concerns, however, is also a weakness in that it lacks a microeconomic component. Freedoms, rights, and liberties, for example, have to be secured by government. Coherent and competent bureaucracies may take decades to construct and may yield benefits more immediately suited to corporate interests than to those of the poor. In providing broad statistical evidence for the importance of social capital, the subtlety, richness, and enormous variation gleaned from case studies of individual countries and communities is lost, as are the voices of those most directly affected by weak public institutions: the poor.

\section{The Synergy View}

In recognition of this disconnect, a number of scholars have recently proposed what might be called a synergy view, which attempts to integrate the compelling work emerging from the networks and institutional camps. Although the synergy view traces its intellectual antecedents to earlier work in comparative political economy and anthropology, its most influential body of research was published in a special issue of World Development (1996). The contributors to this volume examined cases 
from Brazil, India, Mexico, the Republic of Korea, and Russia in search of the conditions that foster developmental synergies - dynamic professional alliances and relationships between and within state bureaucracies and various actors in civil society.

Three broad conclusions emerged from these studies:

- Neither the state nor societies are inherently good or bad; governments, corporations, and civic groups are variable in the impact they can have on the attainment of collective goals.

- States, firms, and communities alone do not possess the resources needed to promote broad-based, sustainable development; complementarities and partnerships forged both within and across these different sectors are required. Identifying the conditions under which these synergies emerge (or fail to emerge) is thus a central task of development research and practice.

- Of these different sectors, the state's role in facilitating positive developmental outcomes is the most important and problematic. This is so because the state is not only the ultimate provider of public goods (stable currencies, public health, universal education) and the final arbiter and enforcer of the rule of law (property rights, due process, freedom of speech and association) but is also the actor best able to facilitate enduring alliances across the boundaries of class, ethnicity, race, gender, politics, and religion. Communities and firms also have an important role to play in creating the conditions that produce, recognize, and reward good governance. In otherwise difficult institutional environments, community leaders who are able to identify and engage what Fox (1992) calls "pockets of efficiency within the state" become agents of more general reform.

Evans $(1992,1995,1996)$, one of the primary contributors to this view, concludes that synergy between government and citizen action is based on complementarity and embeddedness. Complementarity refers to mutually supportive relations between public and private actors and is exemplified in legal frameworks that protect rights of association and in more humble measures such as chambers of commerce to facilitate exchanges among community associations and business groups. Embeddedness refers to the nature and extent of the ties connecting citizens and public officials. The classic examples are from irrigation, in which the lowest-level irrigation officials are from the community being served; they are enmeshed in local social relations and hence are under pressure by the community to perform and be responsive to them. Importantly, this approach works only where the actions of public officials are simultaneously bound by performance-oriented organizational environments that are competent, coherent, and credible. As the case of Russia amply demonstrates, weak public institutions and deep cleavages between powerful authorities and ordinary citizens can lead to political instability, rampant corruption, rising inequality, and capital flight (Rose 1998). 
Developing these ideas, Woolcock (1998) shows that a range of development outcomes flows from different types and combinations of community capacity and state functioning. Narayan (1999) integrates the core ideas of bridging social capital and state-society relations and suggests that different interventions are needed for different combinations of governance and bridging social capital in a group, community, or society (figure 2). In societies (or communities) with good governance and high levels of bridging social capital, there is complementarity between state and society, and economic prosperity and social order are likely. But when a society's social capital inheres mainly in primary social groups disconnected from one another, the more powerful groups dominate the state, to the exclusion of other groups. Such societies, which include countries in Latin America with large excluded indigenous populations, are characterized by latent conflict. In these circumstances, a key task for subordinate groups and activists is to forge broad, coherent coalitions (Keck and Sikkink 1998) and nurture relations with allies in positions of power (Fox and Brown 1998); should they be successful, weak groups may begin to accrue rights and resources previously denied them. Similarly, a state that opens up and explicitly builds bridges

Figure 2. Relationsbip between Bridging Social Capital and Governance

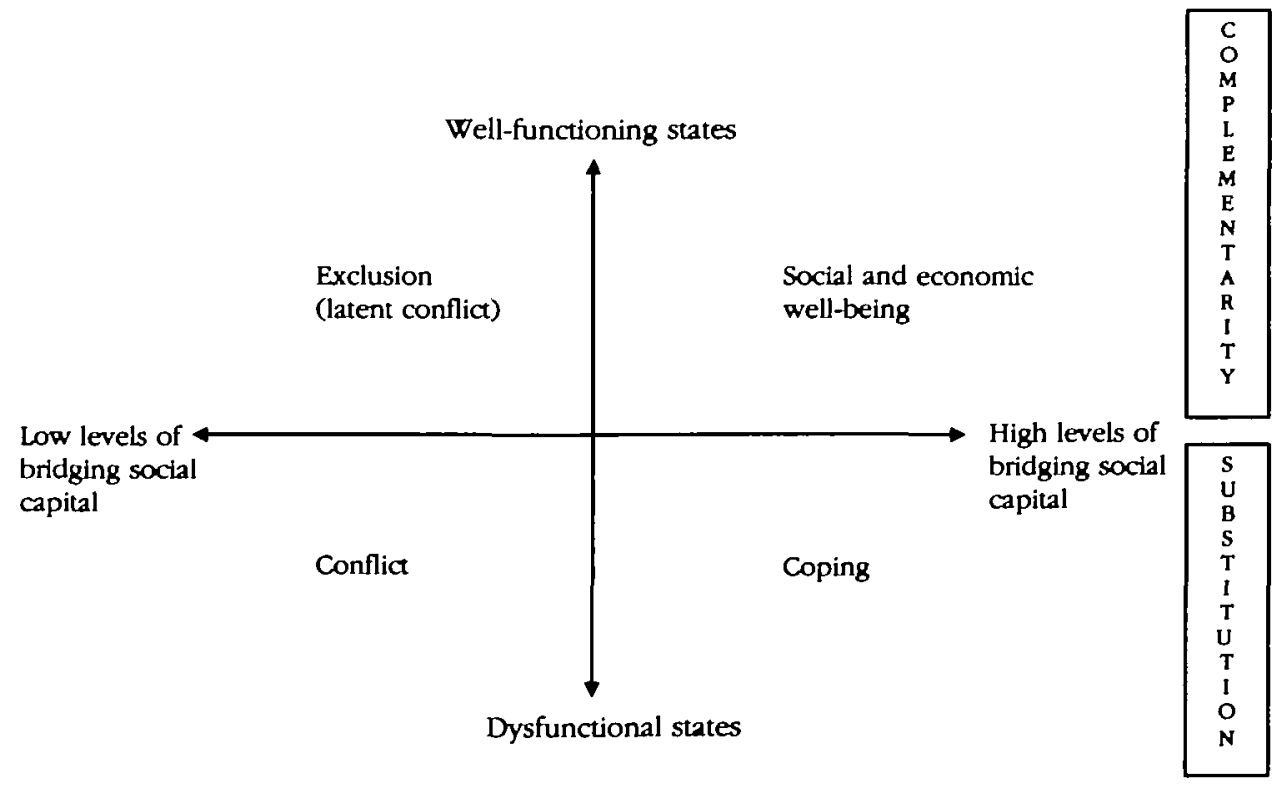

Note: Complementarity refers to the optimal interaction of government and markets in civil society; substitution is the replacement by informal organizations (families, networks, and so on) of services ordinarily provided by governments and institutions.

Source: Adapted from Narayan (1999). 
to excluded groups increases the likelihood that the poor will be able to gain access to the resources and services to which they are entitled.

Alternatively, state-society relations may degenerate into conflict, violence, war or anarchy—a breakdown that allows warlords, local mafias, and guerrilla movements to take over the power and authority of the state. Restoring economic prosperity and peace to Rwanda, for example, will involve forging a measure of reconciliation between two ethnic groups. Often, when citizens are deprived of services and benefits, informal networks substitute for the failed state and form the basis of coping strategies. This is the case in Benin and Togo, where women, denied access to formal credit, established informal revolving credit societies; in Tanzania the absence of police protection has led some villages to rely on their own system of security guards (Narayan and others 2000).

When representatives of the state, the corporate sector, and civil society establish common forums through which they can pursue common goals, development can proceed. In these circumstances social capital has a role as a mediating variable that is shaped by public and private institutions. This shaping is an inherently contentious and political process, one in which the role of the state is crucial. Moreover, the fundamental social transformation of economic development-from traditional kinship-based community life to societies organized by formal institutions-alters the calculus of costs and benefits associated with different dimensions of social capital and the desirable combinations of these dimensions (Berry 1993). Although development struggles are inherently political, they are not always won by the most powerful, nor do challenges to authority always entail violent conflict. Patient efforts by intermediaries to establish partnerships between associations of the poor and outsiders can reap significant dividends (Isham, Narayan, and Pritchett 1995). As Uphoff (1992:273) points out,

paradoxical though it may seem, "top-down" efforts are usually needed to introduce, sustain, and institutionalize "bottom-up" development. We are commonly constrained to think in "either-or" terms-the more of one the less of the other-when both are needed in a positive-sum way to achieve our purposes.

The synergy view suggests three central tasks for theorists, researchers, and policymakers: to identify the nature and extent of a community's social relationships and formal institutions, and the interaction between them; to develop institutional strategies based on these social relations, particularly the extent of bonding and bridging social capital; and to determine how the positive manifestations of social capitalcooperation, trust, and institutional efficiency-can offset sectarianism, isolationism, and corruption. Put another way, the challenge is to transform situations where a community's social capital substitutes for weak, hostile, or indifferent formal institutions into ones in which both realms complement one another. 


\begin{tabular}{|c|c|c|}
\hline Perspective & Actors & Policy prescriptions \\
\hline \multicolumn{3}{|l|}{ Communitarian view } \\
\hline Local associations & $\begin{array}{l}\text { Community groups } \\
\text { Voluntary organizations }\end{array}$ & $\begin{array}{l}\text { Small is beautiful } \\
\text { Recognize social assets of the poor }\end{array}$ \\
\hline \multicolumn{3}{|l|}{ Networks view } \\
\hline $\begin{array}{l}\text { Bonding and bridging } \\
\text { community ties }\end{array}$ & $\begin{array}{l}\text { Entrepreneurs } \\
\text { Business groups } \\
\text { Information brokers }\end{array}$ & $\begin{array}{l}\text { Decentralize } \\
\text { Create enterprise zones } \\
\text { Bridge social divides }\end{array}$ \\
\hline \multicolumn{3}{|l|}{ Institutional view } \\
\hline $\begin{array}{l}\text { Political and legal } \\
\text { institutions }\end{array}$ & Private and public sectors & $\begin{array}{l}\text { Grant civil and political liberties } \\
\text { Institute transparency, accountability }\end{array}$ \\
\hline \multicolumn{3}{|l|}{ Synergy view } \\
\hline $\begin{array}{l}\text { Community networks and } \\
\text { state-society relations }\end{array}$ & $\begin{array}{l}\text { Community groups, civil } \\
\text { society, firms, states }\end{array}$ & $\begin{array}{l}\text { Coproduction, complementarity } \\
\text { Participation, linkages } \\
\text { Enhance capacity and scale of } \\
\text { local organizations }\end{array}$ \\
\hline
\end{tabular}

Table 2 summarizes the key elements of the four perspectives on social capital and development and their corresponding policy prescriptions. The differences between them are primarily the unit of analysis on which they focus; their treatment of social capital as an independent, dependent, or mediating variable; and the extent to which the $f$ incorporate a theory of the state. The largest and most influential bodies of work have emerged from the networks and institutional perspectives; the most recent approaches seek a synthesis.

\section{Measuring Social Capital}

Several recent innovative studies have attempted to quantify social capital and its contribution to economic development. To arrive at concrete policy recommendations for using social capital as a development tool, more comparative research is required that uses precise measures of social capital to examine within-country and across-country variations in poverty reduction, government performance, ethnic conflict, and economic growth. Obtaining a single, true measure of social capital is probably not possible, for several reasons. First, the most comprehensive definitions of social capital are multidimensional, incorporating different levels and units of analysis. Second, the nature and forms of social capital change over time, as the balance shifts between informal organizations and formal institutions. And third, because no long-standing cross-country surveys were initially designed to measure social capital, contemporary researchers have had to compile indexes from a range of approximate items (measures of trust, confidence in government, voting trends, social mobility, 
and so on). Several excellent studies have identified useful measures of, and proxies for, social capital, however.

One measure is membership in informal and formal associations and networks. In developing countries generally, and in rural areas in particular, measures that capture the informal give-and-take through communitywide festivals, sporting events, and other traditional methods of fostering social connections are very important indicators of the underlying stocks of social capital. Based on data from a survey of 1,400 households in 87 villages across Tanzania (Narayan 1997), Narayan and Pritchett (1999) developed an index of social capital at the household and community levels that included density and characteristics of informal and formal groups and networks. The dimensions of this index included group functioning, financial and inkind contributions to groups, participation in decisionmaking, and heterogeneity of membership. A series of measures was also constructed on interpersonal trust and changes over time. These measures demonstrated that social capital was indeed both social and capital, generating returns that exceeded those to human capital.

In tandem with the Tanzania study, studies of local institutions in three countries-Bolivia (Grootaert and Narayan 2000), Burkina Faso (Grootaert, Oh, and Swamy 1999), and Indonesia (Grootaert 1999)—looked at qualitative service delivery issues and quantified these variables. These studies demonstrated that the questionnaire items do in fact capture different dimensions of social capital at the household and community levels, that certain dimensions of social capital contribute significantly to household welfare, and that social capital is the capital of the poor. The most important variables in these studies are density of associations, heterogeneity of membership in associations, and degrees of active participation in them.

Another manifestation of social capital includes norms and values that facilitate exchanges, lower transaction costs, reduce the cost of information, permit trade in the absence of contracts, and encourage responsible citizenship and the collective management of resources (Fukuyama 1995). Inglehart's (1997) work on the World Values Survey is the most comprehensive effort in this area. The questions economists working on social capital find valuable are those on trust ("Generally speaking, would you say that most people can be trusted or that you can't be too careful in dealing with people?"). Knack and Keefer (1997), for example, use these data to show the positive relationship between trust and levels of investment in a country.

Although research attempting to identify the nature of the relationships between social variables and development has recently proliferated, the quality of the data is less than ideal. With mounting pressure to provide simple measures of inherently complex and interdependent relationships, there is a danger that expectations will exceed capacity and that hastily assembled, poorly conceived measures will jeopardize the agenda they purport to serve. One way to strike the balance between quality and quantity measures is to unbundle social capital into its dimensions and to generate new data sets that are comparable across many countries. ${ }^{2}$ 
Four recent studies attempt to develop indices of social capital at the national or subnational levels. In the United States several new surveys of civic engagement are being conducted in addition to the work already collected in surveys of consumer preferences and changes in lifestyles. The National Commission on Philanthropy and Civic Renewal (1998), for example, has developed a National Index of Civic Engagement based on a sample of 1,000 respondents. This index includes five dimensions: the giving climate, community engagement, charitable involvement, the spirit of voluntarism, and active citizenship. Robert Putnam's Saguaro Seminar will soon launch the Social Capital Community Benchmark, a comprehensive survey of social capital in the United States (Putnam 2000).

In exploring the roots and determinants of Hindu and Muslim riots in India, Varshney (2000) focuses on the role of intercommunal networks. In cities where Hindus and Muslims have little interaction, Varshney shows that latent communal conflict has few channels for peaceful resolution and periodically descends into violence; in cities where association memberships overlap and everyday interactions are frequent, conflict is anticipated and dissipated. This research was based on six Indian cities carefully arranged in three matched pairs that were similar in terms of HinduMuslim demographic composition but dissimilar in that one city experienced recurrent riots whereas the other city remained calm. Varshney's work shows that diversity can be a source of strength where social ties transcend different community boundaries.

To assess social capital at the community level, Onyx and Bullen (forthcoming) developed a questionnaire for the state of New South Wales, Australia, from which they isolated eight underlying factors that constituted an individual's social capital: participation in the local community, proaction in a social context, feelings of trust and safety, neighborhood connections, connections with family and friends, tolerance of diversity, value of life, and work connections. Looking only at an individual's social capital score, the authors could predict the community to which the person belonged, thus raising the prospects for this instrument being used for planning and monitoring community development activities.

Building on this work, researchers are working to develop social capital instruments that can be used as diagnostic tools at the community level and across countries. Because the forms of social capital are society-specific and change over time, the instruments must focus on a range of dimensions of social capital (Narayan and Cassidy 1999). Such instruments have recently been introduced in Ghana and Uganda (Narayan 1998) and by the World Bank's Social Capital Initiative in Panama and India (Krishna and Shrader 1999). ${ }^{3}$ Analyses of the data reveal that the dimensions underlying social capital are strikingly similar even when the context is quite different. The Ghana study draws on a sample of 1,471 rural and urban households, while the Uganda study focuses on 950 households in slum communities in Kampala. Factor analyses reveal a similar underlying structure and clustering of variables. 


\section{Implications for Development Theory and Policy}

The concept of social capital offers a way to bridge sociological and economic perspectives and to provide potentially richer and better explanations of economic development. One important way it does this is by showing that the nature and extent of social interactions between communities and institutions shape economic performance. This, in turn, has important implications for development policy, which has long focused exclusively on an economic dimension. Similarly, understanding how outside agencies can work to alleviate poverty in diverse and poorly understood communities remains one of the great challenges of development. A social capital perspective stresses that technical and financial soundness is a necessary but insufficient condition for acceptance of a project by poor communities.

Six broad recommendations can be offered for incorporating the concept of social capital into development policy. First, for development interventions in all sectors and at all levels (especially the country level), social institutional analysis should be used to identify correctly the range of stakeholders and their interrelations. Understanding how proposed policy interventions will affect the power and political interests of the stakeholders is a vital consideration, since all policy interventions occur in a social context characterized by a delicate mix of informal organizations, networks, and institutions. The design of an intervention needs to pay special attention to the potential for dominant groups to mobilize in ways that undermine the public good.

Second, it is critical to invest in the organizational capacity of the poor and to help build bridges between communities and social groups. The latter is particularly important because many decisions affecting the poor are not made at the local level. To this end, the use of participatory processes can facilitate consensus-building and social interaction among stakeholders with diverse interests and resources. Finding ways and means by which to transcend social divides and build social cohesion and trust is crucial for economic development. One of the great virtues of the idea and discourse on social capital is that it provides a common language for these different stakeholders, enabling them to communicate more easily with one another.

Third, a social capital perspective adds its voice to those calling for information disclosure policies at all levels to encourage informed citizenship and accountability of both private and public actors who purport to serve the public good. Fourth, improvements in physical access and modern communications technology that can foster information exchange across social groups should be emphasized to complement social interaction based on face-to-face interchange. Fifth, development interventions should be viewed through a social capital lens, and assessments of their impact should include the potential effects of the intervention on the social capital of poor communities. To reiterate, the social networks of the poor are one of the primary resources they have for managing risk and vulnerability, and outside agents therefore need to find ways to complement these resources, rather than substitute for them. 
Finally, social capital should be seen as a component of orthodox development projects, from dams and irrigation systems to local schools and health clinics. Where poor communities have direct input into the design, implementation, management, and evaluation of projects, returns on investments and the sustainability of the project are enhanced (Esman and Uphoff 1984).

\section{Conclusion}

Although it is too soon to announce the arrival of a new development paradigm, it is not unreasonable to claim that a consensus is emerging about the importance of social relations in development. In unpacking the literature on social capital and development, a recurring message is that social relations provide opportunities for mobilizing other growth-enhancing resources, that social capital does not exist in a political vacuum, and that the nature and extent of the interactions between communities and institutions hold the key to understanding the prospects for development in a given society. The evidence supports the argument that social capital can be used to promote or to undermine the public good. This consideration suggests that one of the most important examples of social capital at work in the absence of formal insurance mechanisms and financial instruments is the use by the poor of social connections to protect themselves against risk and vulnerability.

In many respects the research on social capital is still in its early stages, but practitioners and policymakers cannot wait for researchers to know all there is to know before acting. Instead, all those involved should adopt a stance of learning by doing. This implies more rigorous evaluations of project and policy impact on social capital, more work on unbundling the mechanisms through which social capital works, and understanding the determinants of social capital itself. It also implies that practical lessons emerging from development projects can themselves be used to inform social capital theory.

It would be the ultimate irony if those people most interested in studying social capital and promoting its use in formulating development policy did not themselves foster trust, openness, and a willingness to share information, ideas, and opportunities in this field. Readers are invited to access, use, and contribute to the ongoing research on social capital. ${ }^{4}$ It is only through collaborative efforts-with all that this entails regarding struggle, perseverance, negotiation, and mutual willingness to learnthat genuine progress will be made.

\section{Notes}

Michael Woolcock is a social scientist with the World Bank's Development Research Group and an adjunct lecturer in public policy ar Harvard University. Deepa Narayan is a lead social development 
specialist in the Poverty Reduction and Economic Management Network at the World Bank. For helpful comments on an earlier draft of this paper, the authors thank John Blaxall, Jonathan Fox, Christiaan Grootaert, Bill Mulford, Vijayendra Rao, Anders Rudkvist, and anonymous reviewers.

1. For citations on the first eight fields, see Woolcock (1998) and Foley and Edwards (1999). See also the database of articles on the World Bank's social capital Website, at <http://www.worldbank.org/ poverty/scapital/library/index.htm\#db>.

2. A number of recent survey instruments are available to researchers doing work in this field. See the World Bank's social capital Website, <http://www.worldbank.org/poverty/scapital/library/ surveys.htm>.

3. The World Bank's Social Capital Initiative is a $\$ 1.2$ million dollar project sponsored by the government of Denmark. Several monographs produced for the initiative have been cited in this paper; these and several others can be downloaded at <http://www.worldbank.org/poverty/scapital/ wkrppr/wrkppr.htm >. These papers are currently being edited and prepared for formal publication.

4. The World Bank's Social Capital Thematic Group Website contains instructions on how to receive our newsletter and join the e-mail discussion group. Go to <http://www.worldbank.org/poverty/scapital/s.

\section{References}

The word "processed" describes informally reproduced works that may not be commonly available through library systems.

Astone, Nan Marie, Constance Nathanson, Robert Schoen, and Young Kim. 1999. "Family Demography, Social Theory, and Investment in Social Capital." Population and Development Review 25(1): $1-31$.

Barr, Abigail. 1998. "Enterprise Performance and the Functional Diversity of Social Capital." Working Paper Series 98-1. University of Oxford, Institute of Economics and Statistics, Oxford, U.K. Processed.

Berry, Sara. 1993. No Condition Is Permanent: The Social Dynamics of Agrarian Change in SubSaharan Africa. Madison, Wis.: University of Wisconsin Press.

Briggs, Xavier de Souza. 1998. "Brown Kids in White Suburbs: Housing Mobility and the Multiple Faces of Social Capital." Housing Policy Debate 9(1):177-221.

Brown, L. David. 1998. “Creating Social Capital: Nongovernmental Development Organizations and Intersectoral Problem Solving." In Walter W. Powell and Elisabeth Clemens, eds., Private Action and the Public Good. New Haven, Conn.: Yale University Press.

Brown, L. David, and Darcy Ashman. 1996. "Participation, Social Capital, and Intersectoral Problem Solving: African and Asian Cases." World Development 24(6):1477-95.

Burt, Ronald. 1992. Structural Holes: The Social Structure of Competition. Cambridge, Mass.: Harvard University Press. 65.

. 1997. "The Contingent Value of Social Capital." Administrative Science Quarterly 42:339-

1998. "The Gender of Social Capital." Rationality and Society 10(1):5-46.

Coleman, James. 1987. “Norms as Social Capital." In Gerard Radnitzky and Peter Bernholz, eds., Economic Imperialism: The Economic Method Applied outside the Field of Economics. New York: Paragon House Publishers.

- 1988. "Social Capital in the Creation of Human Capital." American Journal of Sociology 94(Supplement):S95-S120. 
1990. Foundations of Social Theory. Cambridge, Mass.: Harvard University Press.

Collier, Paul. 1998. "Social Capital and Poverty." Social Capital Initiative Working Paper 4. World Bank, Social Development Department, Washington, D.C. Processed.

1999. “The Political Economy of Ethnicity." In Boris Pleskovic and Joseph E. Stiglitz, eds., Annual World Bank Conference on Development Economios 1998. Washington, D.C.: World Bank.

Collier, Paul, and Jan Willem Gunning. 1999. “Explaining African Economic Performance.” Journal of Economic Literature 37(March):64-111.

Dordick, Gwendolyn. 1997. Something Left to Lose: Personal Relations and Survival among New York's Homeless. Philadelphia, Pa.: Temple University Press.

Easterly, William. 2000. "Happy Societies: The Middle Class Consensus and Economic Development." World Bank, Development Research Group, Washington, D.C. Processed.

Escobar, Arturo. 1995. Encountering Development: The Making and Unmaking of the Third World Princeton, N.J.: Princeton University Press.

Esman, Milton, and Norman Uphoff. 1984. Local Organizations: Intermediaries in Rural Development. Ithaca, N.Y.: Cornell University Press.

Evans, Peter. 1992. "The State as Problem and Solution: Predation, Embedded Autonomy, and Structural Change." In Stephan Haggard and Robert Kaufman, eds., The Politios of Economic Adjustment: International Constraints, Distributive Conflicts, and the State. Princeton, N.J.: Princeton University Press.

- 1995. Embedded Autonomy: States and Industrial Transformation. Princeton, N.J.: Princeton University Press.

- 1996. "Government Action, Social Capital and Development: Reviewing the Evidence on Synergy." World Development 24(6):1119-32.

Fafchamps, Marcel, and Bart Minten. 1999. "Social Capital and the Firm: Evidence from Agricultural Trade." Social Capital Initiative Working Paper 17. World Bank, Social Development Department, Washington, D.C. Processed.

Foley, Michael, and Bob Edwards. 1999. "Is It Time to Disinvest in Social Capital?" Journal of Public Policy 19:141-73.

Fox, Jonathan. 1992. “Democratic Rural Development: Leadership Accountability in Regional Peasant Organizations." Development and Change 23(2):1-36.

Fox, Jonathan, and L. David Brown, eds. 1998. The Struggle for Accountability: The World Bank, NGOs, and Grassroots Movements. Cambridge, Mass.: MIT Press.

Fukuyama, Francis. 1995. Trust: The Social Virtues and the Creation of Prosperity. New York: Free Press.

Gittell, Ross, and Avis Vidal. 1998. Community Organizing: Building Social Capital as a Development Strategy. Newbury Park, Calif.: Sage Publications.

Granovetter, Mark. 1973. "The Strength of Weak Ties." American Journal of Sociology 78:1360-80. 1995. "The Economic Sociology of Firms and Entrepreneurs." In Alejandro Portes, ed., The Economic Sociology of Immigration: Essays on Networks, Ethnicity, and Entrepreneurship. New York: Russell Sage Foundation.

Grootaert, Christiaan. 1999. "Social Capital, Household Welfare, and Poverty in Indonesia." Local Level Institutions Working Paper 6. World Bank, Social Development Department, Washington, D.C. Processed.

Grootaert, Christiaan, and Deepa Narayan. 2000. "Local Institutions, Poverty, and Household Welfare in Bolivia." Working Paper 9. World Bank, Social Development Department, Washington, D.C. Processed. 
Grootaert, Christiaan, Gi-Taik Oh, and Anand Swamy. 1999. "Social Capital and Development Outcomes in Burkina Faso." Working Paper 7. World Bank, Social Development Department, Washington, D.C. Processed.

Hall, Robert, and Charles Jones. 1999. "Why Do Some Countries Produce So Much More Output per Worker than Others?" Quarterly Journal of Economics 114(1):83-116.

Hanifan, Lyda J. 1916. “The Rural School Community Center." Annals of the American Academy of Political and Social Science 67:130-38.

Holzmann, Robert, and Steen Jorgensen. 1999. "Social Protection as Social Risk Management." Social Protection Discussion Paper 9904. World Bank, Human Development Nerwork, Social Protection Team, Washington, D.C. Processed.

Homans, George. 1961. Social Behavior: Its Elementary Forms. New York: Harcourt, Brace and World.

Inglehart, Ronald. 1997. Modemization and Postmodemization: Culturah Economic, and Political Change in 43 Societies. Princeton, N.J.: Princeton University Press.

Isham, Jonathan. 1999. "The Effect of Social Capital on Technology Adoption: Evidence from Rural Tanzania." Paper presented at the annual meeting of the American Economic Association, New York. Processed.

Isham, Jonathan, and Daniel Kaufmann. 1999. "The Forgotten Rationale for Policy Reform: The Productivity of Investment Projects." Quarterly Journal of Economics 114(1):149-84.

Isham, Jonathan, Deepa Narayan, and Lant Pritchett. 1995. "Does Participation Improve Performance? Establishing Causality with Subjective Data." The World Bank Economic Review 9(2):175200.

Jacobs, Jane. 1961. The Life and Death of Great American Cities. New York: Random House.

Keck, Margaret, and Kathryn Sikkink. 1998. Activists beyond Borders: Advocacy Networks in International Politics. Ithaca, N.Y.: Cornell University Press.

Knack, Stephen. 1999. "Social Capital, Growth, and Poverty: A Survey of Cross-Country Evidence." Social Capital Initiative Working Paper 7. World Bank, Social Development Department, Washington, D.C. Processed.

Knack, Stephen, and Philip Keefer. 1995. "Institutions and Economic Performance: Cross-Country Tests Using Alternative Institutional Measures." Economics and Politics 7(3):207-27.

- 1997. "Does Social Capital Have an Economic Payoff? A Cross-Country Investigation." Quarterly Journal of Economics 112:1251-88.

Kozel, Valerie, and Barbara Parker. 2000. "Integrated Approaches to Poverty Assessment in India." In Michael Bamberger, ed., Integrating Quantitative and Qualitative Research in Development Projects. Washington, D.C.: World Bank.

Krishna, Anirudh, and Elizabeth Shrader. 1999. "Social Capital Assessment Tool." Social Capital Initiative Working Paper 22. World Bank, Social Development Department, Washington, D.C. Processed.

Loury, Glenn C. 1977. “A Dynamic Theory of Racial Income Differences." In P. A. Wallace and A. LeMund, eds., Women, Minorities, and Employment Discrimination. Lexington, Mass.: Lexington Books.

Massey, Douglas. 1998. “March of Folly: U.S. Immigration Policy after NAFTA." The American Prospect 37:22-33.

Massey, Douglas, and Karin Espinosa. 1997. "What's Driving Mexico-U.S. Migration? A Theoretical, Empirical, and Policy Analysis." American Joumal of Sociology 102(4):939-99.

Moore, Mick. 1997. "Socieries, Polities, and Capitalists in Developing Countries: A Literarure Survey." Joumal of Development Studies 33(3):287-363. 
Moser, Caroline. 1996. Confronting Crisis: A Comparative Study of Household Responses to Poverty and Vulnerability in Four Poor Urban Communities. Environmentally Sustainable Development Studies and Monographs Series 8. Washington, D.C.: World Bank.

Narayan, Deepa. 1995. “Designing Community-Based Development." Social Development Paper 7. World Bank, Environmentally and Socially Sustainable Development Network, Washington, D.C. Processed.

_. 1997. "Voices of the Poor: Poverty and Social Capital in Tanzania." Environmentally Sustainable Development Monograph 20. World Bank, Washington, D.C.

1998. "Social Capital Survey in Ghana-Preliminary Results." World Bank, Poverty Reduction and Economic Management Network, Washington, D.C. Processed.

1999. "Bonds and Bridges: Social Capital and Poverty." Policy Research Working Paper 2167. World Bank, Poverty Reduction and Economic Management Network, Washington, D.C. Processed.

Narayan, Deepa, and Michael Cassidy. 1999. "A Dimensional Approach to Measuring Social Capital: Development and Validation of a Social Capital Inventory." World Bank, Poverty Reduction and Economic Management Network, Washington, D.C. Processed.

Narayan, Deepa, and David Nyamwaya. 1996. "Learning from the Poor: A Participatory Poverty Assessment in Kenya." Environment Department Papers, Participation Series 34. World Bank, Social Policy and Resettlement Division, Washington, D.C. Processed.

Narayan, Deepa, and Lant Pritchett. 1999. "Cents and Sociability: Household Income and Social Capital in Rural Tanzania." Economic Development and Cultural Change 47(4):871-97.

Narayan, Deepa, and Talat Shah. 1999. “Gender Inequity, Poverty, and Social Capital." Background paper prepared for the Policy Research Report on Gender and Development. World Bank, Development Research Group, Washington, D.C. Processed.

Narayan, Deepa, with Raj Patel, Kai Schafft, Anne Rademacher, and Sarah Koch-Schulte. 2000. Voices of the Poor. Can Anyone Hear Us? Voices from 46 Countries. Washington, D.C.: World Bank.

National Commission on Philanthropy and Civic Renewal. 1998. "National Index of Civic Engagement." University of Connecticut, Storrs, Conn.

North, Douglass C. 1990. Institutions, Institutional Change, and Economic Performance. New York: Cambridge University Press.

Onyx, Jenny, and Paul Bullen. Forthcoming. “Measuring Social Capital in Five Communities." Journal of Applied Behavioral Science.

Platteau, Jean-Philippe. 1994. “Behind the Market Stage Where Real Societies Exist” (Parts I and II). Journal of Development Studies 30:533-77 and 753-817.

Portes, Alejandro, ed. 1995. The Economic Sociology of Immigration: Essays on Networks, Ethnicity, and Entrepreneurship. New York: Russell Sage Foundation.

— 1997. "Neoliberalism and the Sociology of Development." Population and Development Review 23(2):229-59.

1998. "Social Capital: Its Origins and Applications in Contemporary Sociology." Annual Review of Sociology 24:1-24.

Portes, Alejandro, and Patricia Landolt. 1996. "The Downside of Social Capital." The American Prospect 26 (May-June):18-21, 94.

Portes, Alejandro, and Julia Sensenbrenner. 1993. "Embeddedness and Immigration: Notes on the Social Determinants of Economic Action." American Journal of Sociology 98(6):1320-50.

Putnam, Robert. 1993. Making Democracy Work: Civic Traditions in Modern Italy. Princeton, N.J.: Princeton University Press. 
. 1995. "Tuning In, Tuning Out: The Strange Disappearance of Social Capital in America." PS: Political Science and Politics (December):664-83. and Schuster.

Rodrik, Dani. 1998. "Where Did All the Growth Go? External Shocks, Social Conflict, and Growth Collapses." NBER Working Paper 6350. National Bureau of Economic Research, Cambridge, Mass.

- 1999. Making Openness Work. Baltimore, Md.: Johns Hopkins University Press.

Rose, Richard. 1998. "Gerting Things Done in an Anti-Modern Sociery: Social Capital Networks in Russiz." Social Capital Initiative Working Paper 8. World Bank, Social Development Department, Washington, D.C. Processed.

Rubio, Mauricio. 1997. "Perverse Social Capital: Some Evidence from Colombia." Journal of Economic Isues 31(3):805-16.

Schafft, Kai. 1998. "Grassroots Development and the Reconfiguration of Local Political Institutions: Local Minority Self-Governance as a Political and Economic Resource for Hungary's Roma Population." Paper presented at the Graduate Student Conference on International Affairs, George Washington University, Washington, D.C. Processed.

Seeley, John R., Alexander R. Sim, and Elizabeth W. Loosley. 1956. Cresturood Heights: A Study of the Culture of Suburban Life. New York: Basic Books.

Skocpol, Theda. 1995. Protecting Soldiers and Mothers: The Political Origins of Social Policy in the United States. Cambridge, Mass.: Harvard University Press.

1996. "Unraveling from Above." The American Prospect 25:20-25.

Temple, Jonathan. 1998. "Initial Conditions, Social Capital, and Growth in Africa." Journal of African Economies 7(3):309-47.

Temple, Jonathan, and Paul Johnson. 1998. “Social Capability and Economic Growth." Quarterly Journal of Economics 113(3):965-90.

Tendler, Judith. 1997. Good Government in the Tropics. Baltimore, Md.: Johns Hopkins University Press.

United Nations. 1951. Measures for the Economic Development of Underdeveloped Countries. New York: United Nations, Department of Social and Economic Affairs.

Uphoff, Norman. 1992. Learning from Gal Oya: Possibilities for Participatory Development and PostNewtonian Social Science. Ithaca, N.Y.: Cornell University Press.

van Bastalaer, Thierry. 1999. "Does Social Capital Facilitate the Poor's Access to Credit? A Review of the Microeconomic Literature." Social Capital Initiative Working Paper 8. World Bank, Social Development Department, Washington, D.C. Processed.

Van Dijk, Meine Pieter, and Roberta Rabellotti. 1997. Enterprise Clusters and Networks in Developing Countries. London: Frank Cass.

Varshney, Ashurosh. 2000. Ethnic Conflict and Civic Life: Hindus and Muslims in India. New Haven, Conn.: Yale University Press.

White, T. Anderson, and Glenn Smucker. 1998. "Social Capital and Governance in Haiti: Traditions and Trends." In The Challenges of Poverty Reduction. Report 17242-HA. Washington, D.C.: World Bank

Wilson, William Julius. 1987. The Truly Disadvantaged Chicago, Ill.: University of Chicago Press.

- 1996. When Work Disappears: The World of the New Urban Poor. New York: Knopf.

Woolcock, Michael. 1998. "Social Capital and Economic Development: Toward a Theoretical Synthesis and Policy Framework" Theory and Society 27(2):151-208. 
1999. "Learning from Failures in Microfinance: What Unsuccessful Cases Tell Us about How Group-Based Programs Work." American Joumal of Economics and Sociology 58(1):17-42.

2000. "Managing Risk, Shocks, and Opportunities in Developing Economies: The Role of Social Capital." In Gustav Ranis, ed., Dimensions of Development. New Haven, Conn.: Yale Center for International and Area Studies.

Forthcoming. Using Social Capital: Getting the Social Relations Right in the Theory and Practice of Economic Development. Princeton, N.J.: Princeton University Press.

World Bank. 1989. "Staff Appraisal Report, Rwanda, Agricultural Services Project." Report 7599RW. Agricultural Operations Division, South-Central and Indian Ocean Department, Africa Region. Processed. Press.

World Development. 1996. Special issue on social capital. 24(6). 